\title{
Ways of Seeing: Staring at and Representing Disfigurement
}

Vision lies at the heart of all medieval responses to disfigurement and difference: modern campaigners for facial equality argue that whilst the visual impact of a different face might be unavoidable, a negative response is almost always conditioned by socialization, that is, prejudice is learned, not inborn. A child growing up with visibly-different parents may realize that difference quite early in life, but will not make value judgments until it witnesses the responses of peers and/or their parents. In medieval culture, the assumption that a disfigured or scarred face might be seen and cause shame underpins the compensation demanded of the perpetrator of the injury (payments which, as we have seen, might continue long after the actual injury itself). The flipside, the exhibition of the judiciallymarked, did not work without an audience to understand the meaning of such marking. Yet the potential for sympathy, rather than derision, from onlookers suggests that the meaning of such marking was far from stable. It clearly motivated some rulers, for example, to disfigure and then seclude their "treacherous" subjects. The visible bramble scratch on the face singled out Helmstan as a cattle rustler, a branded face marked the repeat Lombard thief, noseless hostages were a sign of Cnut's ruthlessness. But difference might also attract attention because of attempts to conceal it: Notker the Stammerer tells the strange tale of a young man who, ashamed of his red hair and lacking a cap to cover it, attended Mass balancing one of his boots on top of his head. The bishop, annoyed at the lack of respect inherent in not removing headgear in church (and this is Notker's point

P. Skinner, Living with Disfigurement in Early Medieval Europe, DOI 10.1057/978-1-137-54439-1_6 
in telling the bizarre story, it seems), seized the boot and cried "Lo and behold all you people, this fool is red-headed!"'

"Vision forces us to face the ugly and horrific," according to Miller. ${ }^{2}$ He continues, "In a harsher age there would be little or no guilt on the observer's part for the emotions [of disgust] that the stigmatized elicit; in ours there is." 3 And Notker's story does seem to bear him out on this: the bishop had no qualms whatsoever in singling out and ridiculing a member of his congregation whose only offence seems to have been his poverty. "Ridicule" is the word that most often stalks examples of disfigurement: a beaten-up man in the Lombard laws was rendered open to it, conspirators in Gregory of Tours were freed in order to be exposed to it, and Aldevrandus, discussed in Chapter 4, was also laughed at for his appearance. In this chapter, however, I want to explore in more detail the broader assumption inherent in Miller's statement-that seeing a disfigured person evoked disgust in medieval viewers and that they felt no shame in being disgusted. I will use the work of Rosemarie GarlandThomson on staring to broaden out the possibilities for visual contacts between those with disfigured faces and those without. "Staring," she says, "is an ocular response to what we don't expect to see...[it] is an interrogative gesture that asks what's going on and demands the story." 4 Although Garland-Thomson, like Miller, draws a contrast between premodern village societies, in which a person "knew everyone they saw," and the sprawling, impersonal world in which most are strangers, she nevertheless opens up interesting analytical possibilities for the medievalist by restoring to the "staree"-the object of stares-a voice and opinion based on the testimonies of modern people with visible differences. ${ }^{5}$ Another point that she makes is that "We don't usually stare at people we know, but instead when unfamiliar people take us by surprise." ${ }^{6}$ Herein lies the first quandary for a person with a disfigurement: if the stranger was an object of curiosity, how much more would a stranger with facial difference be the object of questions, suspicion or even downright hostility? Although we do not have such spectacular cases of misrecognition as exist in early modern archives, the very fact of a face being changed by disfigurement potentially limited mobility, physical and social. ${ }^{7}$ At the same time, we have already met the perceived shame inherent in a disfigurement being noticed. Miller weaves the subject of the stare into his description of medieval honor culture: honor, he comments, "governed... how long you could look at someone or even dare to look at him at all." 8 The male pronoun is suggestive here. 
The subject of looking and staring has engaged theorists of visual culture for some decades, and their work on viewers of pictures and film has been influential in the burgeoning field of disability studies. In this chapter, however, we shall leave the pictorial till later, and firstly explore written accounts. Garland-Thomson's work provides a rich range of possibilities for interrogating medieval texts. As many medieval narratives of disfigurement, and indeed the legal material, often highlight the unexpected in their accounts or additions, and often demand a story be told to justify the inclusion of that material, they may indeed reveal the gaze of authors or protagonists stunned into staring-physical or textual-by what they did not expect to see.

What, though, is "textual staring"? Alongside narratives of actual, eyewitness accounts by the author, two of which are included at some length in the present chapter, I define "textual" staring as a broader spectrum of accounts, where the writer might not be present as an eyewitness, but where the narrative is sufficiently extended to suggest that the author, or reader, or both, are expected to share some pleasure in consuming the scene being described. A possible analogy to this is the modern French literary device of chosisme, the detailed, almost tortured description of events, people and particularly the objects they owned as if through a camera lens. The major difference between this and the textual staring I propose, however, is that chosisme detached these objects and made them tell the story, whilst the scrutiny visible in the medieval texts is packed with details to heighten emotional response to the actors. As we read extended accounts, whether shocked or curiously fascinated, our focus on the text is itself a stare that verges on the uncontrolled. ${ }^{9}$ The account might verge on the prurient (lengthy accounts of the torture of saints have been accused of this), or display an apparent relish in the gory detail that might not be expected of the author. ${ }^{10}$ These are textual prostheses-additions, enhancements, unnecessary to the basic account but deployed all the same. Most of our reporters were, after all, highly-skilled rhetoricians. Gregory of Tours is a master of textual staring, sharing extended and detailed passages of gruesome injuries and murders with his readers, such as the death of Duke Rauching who, having fallen over the threshold of a doorway, is set upon by his assailants who "cut and sliced his head this way and that so that it all looked like a brain (ita minutatim caput eius conliserunt ut simile totum cerebro puteretur)." "Thietmar, as we have seen, actually invites his readers to consider his "ridiculous" face, in a passage that is as out of place in his text as his broken nose is on his countenance. And all writers have a purpose to their texts beyond the 
simple report: to draw a lesson about bodily vanity compared with cleanliness of soul. Accounts in lawcodes of the extraction of bone shards from a wounded head, with highly-ritualized means for measuring their size, also generate a vivid, performative scene: the reader is invited to look at the bone, to imagine the test in metal receptacles, to judge the outcome themselves, but also to remember. But we do not see these injuries directly. Like all the other cases in this study, they are mediated for us, and earlier readers, by their presentation, repeated for a secondary visual consumption in the written record. But what is the reader to make of such accounts? Are they designed to give pleasure even as they shock or horrify us? As William Ian Miller has commented, "Pain and pleasure have such an unseemly relationship, each never quite knowing how to keep neatly to itself." 12

The stare, however, that visual engagement with something that has captured attention for its unexpected qualities, is differentiated by Garland-Thomson from the gaze. The latter-that "oppressive act of disciplinary looking that subordinates its victim"- - has been used to explore the increasingly unequal relationship between doctors and their patients (Foucault's "clinical gaze") and has also been posited as a gendered phenomenon, with the female body its object and the male viewer in the position of power. ${ }^{13}$ Gender theory, however, is not simply confined to the oppositional categories of male and female, but also encompasses other situations of unequal power relations. According to Miller, "Deformity and ugliness... are disordering... they force us to look and notice." ${ }^{4}$ This somewhat complicates the binary between viewer/powerful and viewed/ powerless, as the glance turns to full-on stare that is difficult to resist. James Partridge, in his personal account of becoming and being disfigured, states bluntly, "Staring can simply be accepted as part of the disfigurement package: changing faces is partly to do with getting used to being an object of scrutiny wherever you go." ${ }^{15}$ In fact, once we start to look, we find a lot of staring going on in medieval texts. Gerald of Wales, for example, reflecting on the scar below the nose just above the upper lip with which a certain Erchembald was born, supports this unlikely story of a "miracle of nature" by saying, "I myself saw Erchembald's son, whose name was Stephen, and there is no doubt that he had the same mark. A chance accident had become a natural defect." ${ }^{16}$ Gerald's report, and that of Orderic Vitalis about Walchelin, discussed earlier, suggest not so much disgust as wonder, a phenomenon that Rosemarie Garland-Thomson posits as the reason for the uncontrolled staring which, she suggests, "opens up toward new knowledge." 17 
In a stimulating article utilizing evidence from medical texts, in particular Henri de Mondeville's surgical manual of the thirteenth century, Luke Demaitre proposes that facial difference became a real issue for medical practitioners from this period onwards, when they were faced with "a sharper perception of superficial features, which was no doubt enhanced by the proximity of town life," and concomitantly a demand from urban elites (aristocratic and mercantile) for assistance in remedying conditions that would not have concerned country folk: red or pale skin, sun- or windburn, dark or ugly complexion, an excess or lack of hair or beard. ${ }^{18}$ The next chapter will expand on the earlier types of treatment that might have been available for rather more serious disfigurements, but Demaitre's study centers on two issues. The first was the widening-out of a wealthy class able to pay doctors for cosmetic and other enhancements to their appearance, previously the preserve of a very narrow elite. The second, and pertinent to the current discussion, is the idea that town life, with its crowds, public spaces and frequent need to interact with others, led to "changes in sensitivity" about personal appearance. Clearly the conditions that are described here are some way along the spectrum from the disfigurements and injuries that have attracted our attention so far. Whilst largely accepting the economic factor Demaitre posits-there is little doubt that the link between material prosperity and "worried well" is not simply a modern phenomenon-I am troubled by the chronology he proposes. ${ }^{19}$ After all, as we have seen, appearances in public assemblies, and proximity to observers, had been features of early medieval legislation regarding facial appearance, and translating Apuleius's Herbarium into Anglo-Saxon surely suggests that curing "uncouth blisters that sit on a man's neb" was not simply an intellectual exercise. ${ }^{20}$ The change he identifies, however, relates as much to the increasing intensity of texts dealing with the surface of the body, as the rising and concentrated populations of towns. Moreover, the apparent triviality of some of the conditions he discusses suggests that people were scrutinizing themselves a lot more closely, a point that we shall return to.

\section{Case Study: Byzantine Staring}

This raises the question of how much staring was going on. Can we access the stare or the gaze in the medieval evidence? I want to use two Byzantine authors, Michael Psellos (d. c. 1078) and Anna Komnena (d. 1153), whose texts contain multiple examples of blindings and mutilation, 
to explore how their descriptions evoke a visual image in the reader's mind, and whether it is possible that any of the episodes were reported by eyewitnesses. Psellos is in fact a useful barometer, reflecting on the right and wrong times to use blinding and disfigurement, and his extended description of nose-cutting as a practice of the "Scythians," not of cultured, Byzantine society, reflects the theme of facial violence as done by Others. ${ }^{21}$ Many of the examples he describes, however, evoke sympathy for the victims, most apparently in an extended episode in which he is a direct eyewitness. ${ }^{22}$ The scene is the downfall of Emperor Michael V and the nobilissimos Constantine (brother of John Orphanotrophos), who sought refuge from the mob in the Studite monastery. Following them in, along with a baying mob, Psellos is greeted by the sight of the two fugitives hanging on for dear life to the altar, and he comments at length on how this pitiable sight moved him to tears rather than the anger he had felt at the men. At the same time, the threat from the mob outside remained, and Psellos builds the tension by adding: "I was fascinated by the drama of the thing." ${ }^{23}$ The standoff in the church continues until a new officer comes with orders to remove the fugitives, promising that they will not be harmed. When they refuse, the sanctuary of the church is breached (illegally, as Psellos notes), and the crowd and officers drag the two fugitives outside "like wild beasts," heedless of their cries of anguish. Having set the story up as a drama, Psellos now switches the action back to the palace, where the fate of Michael and Constantine is being discussed. Finally, it is agreed that they present too much of a danger to be allowed to remain unscathed, but that killing them would be equally risky. A party of men is therefore sent to the monastery with orders to put out the fugitives' eyes, provided that this is done outside the church. Back at the church, of course, the victims are already outside and awaiting their fate, so the newcomers sharpen the branding-iron and prepare to do the deed. At this point "The emperor [Michael]... moaned and wailed aloud and... begged for help. He humbly called on God, raised hands in supplication to Heaven, to the Church, to anything he could think of." By contrast, his uncle remained silent,

braced himself for the trial and... faced suffering bravely....Seeing the executioners all ready for their work, he at once offered himself as the first victim and calmly approached them. They waited with hands athirst for his blood. As there was no clear space between himself and the mob... the Nobilissimus quietly looked round for the man to whom the miserable job had been 
entrusted. "You there," he said, "please make the people stand back. Then you will see how bravely I bear my calamity!"

When the executioner tried to tie him down, to prevent movement at the time of blinding, he said, "Look here, if you see me budge, nail me down!" With these words he lay flat on his back on the ground... His eyes were then gouged, one after the other. ${ }^{24}$ Meanwhile the emperor, seeing in the other's torment the fate that was about to overtake him, too, lived through Constantine's anguish in himself, beating his hands together, smiting his face, and bellowing in agony. The Nobilissimus, his eyes gouged out, stood up from the ground and leaned for support on one of his most intimate friends... With Michael it was different, for when the executioner saw him flinch away and lower himself to base entreaty, he bound him securely. $\mathrm{He}$ held him down with considerable force, to stop the violent twitching when he was undergoing his punishment. After his eyes, too, had been blinded, the insolence of the mob, so marked before, died away, and with it their rage

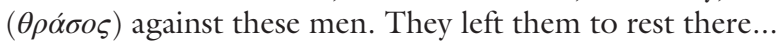

Psellos's extended treatment of this blinding is occasioned by the fact that he was there throughout - he literally gives us a blow-by-blow account of the "drama" that he was fascinated by, as if compelled to continue watching. ${ }^{25}$ Although ostensibly in a position of power as he watches the scene unfold, he is in fact rendered powerless and in tears by the anguish of the two victims. But there are other gazes at work here: the crowd pushing and struggling to be "the first witness of their punishment," Constantine's cool and direct address to the commander of the blinding party, the terrified Michael, watching his companion's mutilation and unable to mirror the older man's bravery, and finally the executioner, seeing the flinching man and forced to bind him securely in order to do his job (blinding, not killing) properly.

Anna Komnena's descriptions of the blindings and mutilations during her father's rise to power and his emperorship are both consistent in conveying the horror of such actions and yet curiously full of detail, providing for her readers a spectacle of punishment. Unswervingly loyal to her father's memory, she presents him as a man who "thought capture was punishment enough for an enemy," willing at times to threaten and even to simulate blindings as part of elaborate ruses to flush out traitors, but distanced (in her text at least) from those occasions when it was actually carried out. ${ }^{26}$ For example the rebel Basilacius, captured by Alexius when he was still acting as Domestic of the scholae, was taken away by the emperor's men (my emphasis) to "some place called Chlempina, and near 


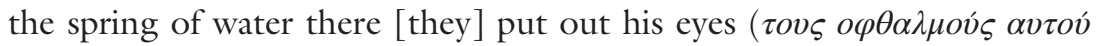
$\varepsilon \xi o \rho v \tau \tau o v \sigma ı \nu)$. Ever since then to this day it has been called 'the spring of Basilacius." 27 The topographic detail calls to mind ritual sites of martyrdom, and may even convey ambivalence about the act itself. Anna is less convincing when she tries to remove her father from involvement in the blinding of the rebel Nicephorus Diogenes: Alexius spreads a rumor that Nicephorus had been secretly blinded, in order to dash his supporters' hopes. But then "certain men" blinded him and another conspirator anyway, and Anna remarks coyly that, "I have been unable so far to discover anything for certain" about whether Alexius ordered or consented to this. ${ }^{28}$ As we shall see, however, she does give Nicephorus's story a happy ending, retired and apparently reconciled to his lack of sight. ${ }^{29} \mathrm{~A}$ third blinding, of her husband's father Bryennius, is referred to only obliquely; she refers the reader to her husband's own history for the details, but repeatedly absolves Alexius of involvement. ${ }^{30}$

If Anna's Alexius was reluctant to blind, his repeated use of threat, rumor and simulation suggests nevertheless that-to Anna at least-resort to such tactics could be justified in times of war. ${ }^{31}$ Anna's lengthy account of the feigned "blinding" of Roussel, early in her book, is graphic in its detail but also remarkably similar to Psellos's earlier set-piece account:

The man was stretched out on the ground, the executioner brought the branding-iron ( $\sigma i \delta \eta \rho o \nu)$ near to his face, and Roussel howled and groaned; he was like a roaring lion. To all appearances he was being blinded. But in fact, the apparent victim had been ordered to shout and bawl; the executioner who seemed to be gouging out his eyes ( $\varepsilon \xi \circ \rho \dot{u} \tau \tau \omega \nu$ again) was told to glare horribly at the prostrate Roussel and act like a raving madman - in other words, to simulate the punishment. So he was blinded ( $\alpha \pi \varepsilon \tau v \phi \lambda o \hat{u} \tau o)$, but not in reality, and the people clapped their hands and noisily spread

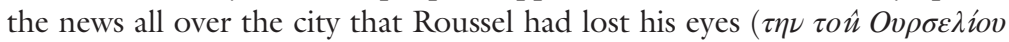
$\tau \dot{u} \varphi \lambda \omega \sigma l \nu) .{ }^{32}$

Note again the fact that this punishment is being carried out with an audience looking on-there would have been no point in pretending to blind Roussel in secret or private, since the object of the exercise is to convince the crowds of Alexius's authority. So convincing is the pantomime that even Alexius's cousin is fooled:

[Dokeianos saw Roussel], "wearing the bandages, apparently blinded $(\tau \alpha$

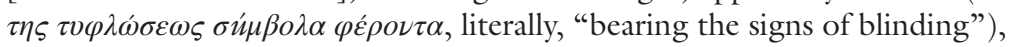


and being led by the hand. He...accused my father of cruelty...[Alexius] took [Dokeianos] to a little room and there uncovered Roussel's head and disclosed his eyes, fiercely blazing. Dokeianos was astonished at the sight; the miracle filled him with wonder and amazement. Again and again he put his hands on Roussel's eyes... When he did learn of his cousin's humane treatment of the man and with his humanity his artifice, he was overcome with joy. ${ }^{33}$

Both accounts are so vivid that it is tempting to suggest they might even have been a favorite story of Anna's father. The description of the fake blinding builds atmosphere with its attention to both visual and auditory cues - the glowing hot iron, the glaring executioner, the roaring, bawling victim and the raving perpetrator, all contributing to imagining the scene. (Sounds had also featured heavily in Psellos's account, too-textual staring is clearly a multisensory experience.) ${ }^{34}$ Yet Anna's literary skills derived as much from her reading and education as her imagination: the "big reveal" in front of Dokeianos owes more to hagiography than history - the removal of bandages, the "miracle" filling him with wonder, and the repeated physical touching of Roussel as evidence that yes, his eyes were indeed still intact. In both passages, the reader is immersed in an imbricated series of scenes and actions, all designed to impress with the guile of Alexius in the service of mercy. Witnessing the apparent horror of blinding, we are doubly relieved and impressed-as Dokeianos is - to find it has not taken place at all. But the sheer fear of blinding is convincingly displayed in both real and fake situations.

Anna is not done with us yet, however. She inserts her own gaze into the text when she recounts the humiliation of the rebel Michael Anemas and his brothers. Having been shaved completely, and their beards cut off, the rebels were mounted sideways on oxen, dressed in sackcloth, and "crowned" with entrails before being driven through the palace courtyard to their blinding. Attention was called to this spectacle by criers walking ahead, singing parodic songs (an inversion of the praises of the emperors), and

People of all ages hurried to see the show; we too, the princesses, came out for the same purpose secretly... ${ }^{35}$.

As Michael gestures toward the palace that he would rather be dismembered and beheaded, however, Anna is overcome with pity and begs her mother, the empress, to intercede, thereby saving Michael's sight. 
The elaborate visual and auditory spectacle laid on for the "people" is not meant to be witnessed by the princesses-hence their secrecy in coming out to watch. Whether Anna's memory of the event and her part in it is credible, it is clear that she wants the reader to see the spectacle through her younger eyes, and to be as distressed as she was by Michael's pleading gaze. ${ }^{36}$ (Again, there is a strong parallel with Michael Psellos's own feelings of pity for the victims.) The parading of a traitor through the Agora is repeated soon afterwards in another case, but Alexius only "pretended he wished to blind Gregory," settling instead for his hair and beard to be "shaved to the skin" before displaying him. ${ }^{37}$ The public parading of enemies and criminals, of course, was nothing new: there are plenty of earlier examples (including the exhibition of the antipope Pope John XVI), ${ }^{38}$ and so when the educated Anna was looking for inspiration for her reports, it is not unlikely that she found examples to imitate.

Such set-piece narratives are not just part of Byzantine writing in the twelfth century, however: Orderic Vitalis similarly ramps up the tension in his account of King Henry I of England's condemnation of Luke of La Barre, found guilty of spreading scurrilous songs about the king, to blinding. Here, others spring to Luke's defense, but to no avail. Luke, who "knew that he was condemned to everlasting darkness in this life" and chose instead to die, then

struggled desperately to injure himself as the officers pinioned him. Finally, beating his head like a madman on the walls and stones as they held him, he perished miserably, greatly mourned by all who knew his valour and merry jests. ${ }^{39}$

The two accounts differ in their outcome: Henry I's failure to be merciful toward Luke of La Barre (and to two knights captured and blinded at the same time) leads to all three being memorialized by Orderic, Luke himself preferring suicide, and the king being presented as unjustly harsh (though Orderic never says so directly). Michael, on the other hand, is spared by Alexius Comnenus on the special pleading of his wife and daughter. For Anna, in fact, her father was almost uniformly merciful when it came to blinding and mutilation: regardless of accuracy (and she admits at one point that she will be accused of favoring her father) her text makes it clear that these are things Others do-the Norman leader Robert Guiscard and his son Bohemond are seen cruelly mutilating to extort money, and 
blinding or threatening to blind their opponents; she also reports on Alexius and his brother being faced with a plot to "get rid of them by gouging out their eyes on a trumped-up charge;" and, by far the most bizarre, the blinding inflicted on the Sultan of Iconium, Malik-Shah, by the Turks working for his brother, Mas'ud:

As the instrument normally used for the purpose was lacking, the candelabrum given to Malik-Shah by the emperor took its place-the diffuser of light had become the instrument of darkness and blinding. However, he could still see a small ray of light and when he arrived at Iconium, led by the hand of some guide, he confided this fact to his nurse and she told his wife. In this way the story reached the ears of Mas'ud himself. ${ }^{40}$

Malik-Shah is swiftly eliminated by strangling on his brother's orders.

The Byzantine texts, in fact, mirror a wider development visible in narrative sources in the eleventh, and particularly the twelfth century, that increasingly associates disfigurement and mutilation with injustice or the actions of strangers and enemies. Just as being disfigured risked marginalizing a person, so inflicting disfigurement came to be a sign of alterity. It is notable that the examples of deliberate blinding in Abbot Guibert of Nogent's autobiography are carried out by Bishop Gaudry of Laon's “African man" and by Alais, mother of John of Soissons, already discussed. ${ }^{41}$ And Guibert notes that the vicious mutilations of eyes and feet that accompanied a dispute between Godfrey of Namur and Enguerrand of Boves left a visible legacy, "as is plainly apparent today to anyone visiting the county of Porcien." 42 Was Guibert staring as intensely as his Byzantine contemporaries? He certainly noticed facial difference: reporting the murder of Gérard of Quierzy, he notes that Gérard had only one eye to turn round on his assailant, and he discusses at length the murder of Bishop Gaudry, the mutilation of his body, and the means used to recognize him (a scar on his neck) when his face was so badly disfigured. ${ }^{43}$

Like Orderic Vitalis, Guibert also recounts stories of disfigurement linked to the supernatural, although the facial injury visible in Guibert's tale of a "benign and simple" monastic novice is somewhat more prosaic than Orderic's story of Walchelin. The novice was pursued by the devil while answering the call of nature and injured his forehead against the privy door: the devil was able to injure his body, Guibert comments, but powerless against the monk's purity of soul. ${ }^{44}$ 


\section{Depicting Disfigurement: Iconographic Challenges.}

Medieval texts describe, and allow readers to stare figuratively at, the scenes of disfigurement and mutilation they recount. The ubiquity of modern images of people with disfigurements, across the internet and print culture, in collections such as Wellcome Images, as well as in specifically-commissioned projects such as that sponsored by the Saving Faces charity, allows for staring and contemplation at one remove from the reality of scarred flesh or missing facial features. ${ }^{45}$ Yet in early medieval iconography the actual appearance of people is rarely explored in detail. Even depictions of prominent figures, such as those depicted in the bible of the Carolingian Emperor Charles the Bald at S. Paolo fuori le Mure in Rome, or the series of portraits of early Lombard rulers (including the Franks Pippin the Short, Louis the Pious and Lothar I, and Princes Arechis and Adelchis of the Lombards) on the eleventh-century Codex Legum Langobardorum at the abbey of Cava near Salerno in Italy, are all facially alike, presented bearded, redcheeked, furrow-browed in seriousness and, of course, unblemished. Paul Edward Dutton in fact comments specifically on the "fusion" of identities present in the richly decorated bible, with the Charles medallion perhaps representing Charlemagne, or Charles the Bald, or intentionally fusing both men with the biblical King David. ${ }^{46}$ The German abbess Herrad of Landsberg's famous series of portraits of her fellow nuns in her twelfth-century text the Garden of Delights, similarly, presents a largely undifferentiated series of faces, for all that the sisters are labeled with names to identify them. ${ }^{47}$ This reluctance to depict reality is matched by the sheer reticence of medieval iconography before about 1250 to engage with the disfigured face. Mutilated or impaired bodies do occasionally feature in medieval images, especially of the blind and the lame, complete with crutches or other mobility aids. But the maimed face remains elusive. Why? Willibald Sauerländer suggests that:

...from the time of Charlemagne (r. as emperor 800-814) to the days of Dante (1265-1321) we encounter not a single portrait in the modern sense... Like nature, the natural face was considered unworthy of transmission to posterity. The soul would be raised to heaven...but flesh and bones... would turn to dust and ashes, and thus the earthly faces of mortals were not remembered in portraiture. ${ }^{48}$ 
We have met this sentiment before, in Thietmar's remarks about his own face. He tells us what it looks like, but dismisses his appearance as unimportant compared to the purity of his soul. Early medieval iconography, seemingly, has little to contribute to our knowledge of how people really appeared, in their depictions of the uninjured or the afflicted. Andre Grabar and Carl Nordenfalk offer some explanations: after the achievements of late Roman portraiture, Merovingian art, they suggest, reflected the iconoclastic distaste for depictions of the human figure altogether; paintings of the Carolingian period, by contrast, focused on the pedagogical theme of Christ's life on earth. The Charles the Bald bible, with its illustrative material, simply reflects and extends the concern of medieval clerical writers to situate their accounts within a Christian, biblical framework of understanding. Only occasionally do we meet anything approaching a "portrait," such as that of the priestly donor in the ninth-century decoration of the church of S. Benedetto Malles near Bolzano, Italy. Even donor portraits have their problems, not least in examples of twelfthcentury "retrospective" paintings and depictions of much earlier donors, a parallel of this period's intense interest in re-asserting claims to property through the editing and outright creation of early donation charters into cartularies. ${ }^{49}$ Otherwise, the theme of painting and book illumination was entirely religious and generic. There are depictions of those healed by Christ, so we do have some impairments illustrated in rudimentary ways, but the only really distorted facial features are those of devils in hell. ${ }^{50}$

Images were not totally without meaning of course-even the generic, stern-faced king-portraits in the Cava manuscript were designed to convey authority alongside the legal material copied there, whilst the internal unity of Herrad's community was emphasized by its iconographic uniformity. And the power of images was certainly expressed when people took the trouble to destroy or obliterate them, as occurred during the two waves of iconoclasm - the destruction of holy images - in the Byzantine Empire in the eighth and ninth centuries This, though, was not the same as the defacing of ruler portraits: the iconoclasts expressed opposition to a belief in the power of images as intercessors with God, whilst removing the faces of ruler portraits was a targeted attack on items associated with the deposed or disgraced ruler. Yet it is notable that the faces were removed, rather than disfigured: all memory of that person was to be erased. Thus when Empress Zoe was exiled and had her hair cut, the portrait of her in Hagia Sophia, Constantinople, was also removed. When she was restored, so was her portrait. ${ }^{51}$ 
The stained glass windows at Canterbury cathedral, depicting some of the miracles of Thomas Becket, include the episode of the blinding, castration and subsequent restoration of Ailward of Westoning. Yet, despite one of the panels showing the actual moment of the attack, the artists clearly decided not to portray Ailward after the deed, instead halting at precisely the moment he is looking up at his assailants, bearing down on him with a sharpened implement. ${ }^{52}$ Again, just as in textual accounts, the viewer is left to visualize for him- or herself the aftermath of the mutilation.

\section{SeEING, LoOKIng ANd SelfHood}

Clearly, being deprived of sight by violence was a terrifying ordeal, and it excited the curiosity and pity of those who wrote about it. Moreover, as the story of Malik-Shah illustrates, the process of blinding could be botched, leaving partial sight, and there was always the risk that gouging too far could compromise the intended "mercy" of preserving the life of the victim. ${ }^{53}$ Yet Garland-Thomson remarks that the "ocularcentric" modern world underestimates "the advantages of blindness, such as being able to navigate without artificial light or engaging fully with other senses such as touch and smell." ${ }^{54}$ This sentiment is nicely illustrated by two stories recounted by Gerald of Wales in the twelfth century. One concerns a prisoner at Chateauroux whose eyes had been put out. "From long familiarity with them [he] had committed to memory all the passageways of the castle and even the steps which led up to the towers," and used this knowledge to take hostage the son of the castellan. ${ }^{55}$ Here the rehabilitative intention in the blinding clearly had not had any effect. The castellan of Radnor castle, by contrast, having impiously spent the night with his dogs in the church of St Afon and awoken to find himself blind and his dogs mad, initially "passed his days in tedium and distress," before making a pilgrimage to Jerusalem and dying in battle there, so ending his life "with honor." 56 This apparent rehabilitation, of course, is in response to a supernatural event, but as we shall see there are cases of blinding victims who are portrayed as overcoming their pain and sightlessness to pursue other avenues to fulfillment.

The textual staring apparent in some of the extracts presented here highlights the power of sight and the intensity of the stare or gaze. Eyes are, after all, not only able to take in the world, but are also the key to communication with others. As Miller points out, if eyes can give offence by staring for too long, they can also ward off with a glare: "they tell the 
intruder to back off." ${ }^{57}$ This, though, assumes that the person being stared at was capable of returning the look, and this was by no means universally the case in medieval society. In particular, tropes of modesty surrounding women demanded that they kept their eyes cast down before men. ${ }^{58}$

We have already noted that blocking a woman's or girl's way (wegworin) attracted a penalty in Frankish and Lombard laws. ${ }^{59}$ But what was at stake here? This group of laws has usually been treated as one of a set that envisages, and prohibits, the intrusion of men into the inviolable space occupied by a woman's body. ${ }^{60}$ Whilst some laws explore this intrusion literally-violating the spatial boundary by touching the hand, arm or breast, bursting into a house and illegally cutting a woman's hair, abducting her, engaging in sex-way-blocking, it seems to me, operates somewhat differently, and is inextricably bound up with ways of seeing and looking. Several possibilities offer themselves: blocking a woman's way was an inherently threatening act even without touch; ${ }^{61}$ blocking a woman's way forced her off a path or road and caused physical discomfort if it involved treading in mud or dirt (assuming that the track itself was recognizably drier or smoother than its edges); or blocking a woman's way involved engineering bumping into her, thereby bringing about a moment of illicit physical contiguity. But this last scenario assumes that she is not looking where she is going, that is, that her gaze is a modest one, directed to the ground, not to what lies ahead of her. Did the woman who was looking where she was going indirectly challenge men to get in her way? Such is the double standard still employed in asking women to modify their behavior to avoid unwanted male attention. ${ }^{62}$

Much of the early medieval material on representations of disfigurement feature reports of those who were staring at the facially-different person, but what about the man or woman in the mirror? To what extent was staring at oneself even possible in the early Middle Ages? Demaitre's point about townsmen and women becoming more self-conscious of their looks suggests that another phenomenon was taking place. The "discovery of the individual" in the eleventh and twelfth centuries, longargued by historians from Colin Morris onwards, may not only have included a heightened awareness of social, religious or even racial difference, but also a more constant scrutiny of one's own looks. ${ }^{63}$ Certainly we have plenty of later medieval examples not only of iconography featuring mirrors, but also extant examples of mirrors themselves, which had made the transition from polished metal to worked glass in western Europe by the twelfth century. ${ }^{64}$ Since the latter would have been a 
luxury item (the technology of glassmaking being jealously guarded by the artisans of Venice and regulated by the city authorities), part of the veritable boom in consumer goods in medieval towns, there may be a very strong correlation between the chronology of mirror consumption in the thirteenth and fourteenth centuries and the demand for cosmetics and cures identified by Demaitre. Yet this is clearly an elite phenomenon, and whilst evidence survives for the use of mirrors before 1200 (particularly in Muslim Spain), the kind of self-scrutiny portrayed in later medieval texts and iconography does not appear to have been a feature of early medieval culture. It might be objected that anyone could look at himself or herself in a pool of still water, that mirrors were not necessary for an individual to realize he or she looked different. This is certainly true, but if the overwhelming message preached in the churches was of the ephemerality of the flesh and a criticism of vanity, then looking at oneself, facially whole or not, may have been a less obsessive pastime than it is in modern culture. Moreover, the quality of metal and early glass mirrors possibly distorted the reflection so much that there was really little purpose in looking.

We have met textual staring as a phenomenon, encouraging the reader to contemplate and become involved with vivid scenes of other people's suffering. And texts functioned too as a way to encourage readers, particularly those in power, to consider their own behaviors, the so-called "mirrors-for-princes" literature ${ }^{65}$ Mirror metaphors, in fact, were utilized early by church fathers to express the idea of divine wisdom-if Man was made in God's image, then a perfect life would represent a perfect mirror of God. ${ }^{66}$

And if this were true, then fleshly deformity of any kind did not matter. After all, the doctrine of heavenly resurrection promised a new start, free of impairments. ${ }^{67}$ This, I believe, is why so many of the narrative accounts of disfigurements and mutilations focus on the process of disfigurement rather than its result, and do so often at some length, involving the reader in a shared spectacle. Stories of disfigurement and mutilation recounted by medieval authors, bound up as they often are with ideas of morality and justice, are making of disfigured people's faces a mirror of broader mores and acceptable or illicit actions. Returning to William Ian Miller's point with which we started, I suggest that any disgust that onlookers felt was centered around the cruelty of disfigurement, not its results. They are commenting on extremes of behavior, working out at what point it is morally wrong to inflict a permanent scar. Legislators are doing the same 
thing, and claiming the authority to engage in similar actions, but here the textual stare is often about how the victim is affected by an illegal injury, hence the detailed scrutiny and description of pieces of bone, effusions of blood and lasting impairments. A changed face-even a temporarily changed face-signals a breakdown in social relations. A permanently changed face might require the intervention of the saint if it was unjustifiably changed by the excess force of a powerful perpetrator. If Henry I ever stopped to stare at those whom he had ordered blinded, did he feel any remorse for his actions? Perhaps not, but his order to blind is held up to the reader as one of many examples not to follow. One of the main horrors of disfiguring acts in the early Middle Ages, we might suggest, was the fact that many were so permanent, not amenable to any kind of rehabilitative treatment. Yet ambivalence remained: a disfigured face could be a lesson in humility and ultimate salvation. Medical treatment, then, risked going against God's will (hagiography certainly underlines this). But the early medieval period was not entirely without recourse to care and rehabilitation, as the next chapter will illustrate.

\section{Notes}

1. Notker, Gesta Karoli, I.18, ed. H. Haefele, MGH SS rer. Ger. n.s, XII, (Berlin: Weidmann, 1959); Einhard and Notker the Stammerer, Two Lives of Charlemagne, tr. L. Thorpe (London: Penguin, 1969), 111.

2. William Ian Miller, The Anatomy of Disgust (Cambridge, MA: Harvard University Press, 1997), 19.

3. Ibid., 200.

4. Rosemarie Garland-Thomson, Staring: How We Look (Oxford: Oxford University Press, 2009), 3. I am grateful to Edward Wheatley for pointing me towards Garland-Thomson's work.

5. Garland-Thomson, Staring, 33. For her historical perspective, Garland-Thomson relies rather uncritically on Lyn H. Lofland, $A$ World of Strangers: Order and Action in Urban Public Space (New York: Basic Books, 1973), which itself seems to make sweeping assumptions about the medieval and early modern worlds.

6. Staring, 3.

7. The classic case is of course the sixteenth-century story told in Natalie Zemon Davies, The Return of Martin Guerre (Cambridge, MA: Harvard University Press, 1984). See also her "Remaking 
impostors: from Martin Guerre to Sommersby," Hayes Robinson Lecture Series, I (Egham: Royal Holloway University of London, 1997). The transition between community-based recognition and state-controlled documentation is traced by Valentin Groebner, Who Are You? Identification, Deception and Surveillance in Early Modern Europe (New York: Zone Books, 2007).

8. William Ian Miller, Eye for an Eye (Cambridge: Cambridge University Press, 2006), 101.

9. Garland-Thomson's "baroque staring", described as "shamelessly stimulus-driven, flagrant, open-mouthed, unapologetic... urgent": Staring, 50. Miller, Anatomy of Disgust, 196, expresses something of the same phenomenon in the "double disgust" felt by observers of cruelty - first, disgust at the perpetrator, then disgust and horror at the sight of the "degraded victim, whether bloody or disfigured."

10. On prurience and saintly torture, see Martha Easton, "Pain, torture and death in the Huntingdon Library Legenda aurea," in Gender and Holiness: Men, Women and Saints in Late Medieval Europe, ed. Sam Riches and Sarah Salih (London: Routledge, 2005), 49-64. Extended contemplation of images of such martyrdom was, of course, increasingly central to affective, devotional activity in the later medieval period.

11. GT, IX.9. The motif of stretching over a doorsill recurs in Theophanis Chronographia, AM6203/710-11 CE, ed. C. de Boor, 2 vols (Hildesheim: Georg Olms, 1963), when Justinian II's son Tiberius is killed in the same way.

12. Miller, Eye for an Eye, 58.

13. Garland-Thomson, Staring, 9 (quote), 28 (Foucault) and 41 (gender, citing Laura Mulvey, Visual and Other Pleasures: Theories of Representation and Difference (Bloomington: Indiana University Press, 1989)).

14. Miller, Anatomy of Disgust, 82.

15. James Partridge, Changing Faces: the Challenge of Facial Disfigurement (London: Penguin, 1990), 89-90.

16. Gerald of Wales, The Journey through Wales, II.7, tr. L. Thorpe (London: Penguin, 1978), 190-1.

17. Garland-Thomson, Staring, 51. 
18. Luke Demaitre, "Skin and the city: cosmetic medicine as an urban concern," in Between Text and Patient: The Medical Enterprise in Medieval and Early Modern Europe, ed. Florence Eliza Glaze and Brian K. Nance (Florence: SISMEL-Edizioni del Galluzzo, 2011), 97-120, at 110 .

19. "Worried well" has taken root in both media and clinical reports, as the numerous online articles and 33 specific title entries on the PubMed database attest.

20. Leechdoms, Wortcunning and Starcraft of Early England, 3 vols, ed. O. Cockayne (London: Longmans Green, 1864, 1865 and 1866), I, 87. Cockayne translated neb as "face." "Complexion" is an alternative here.

21. For his account, see above, Chap. 3.

22. The following translated excerpts are drawn from Fourteen Byzantine Rulers: the Chronographia of Michael Psellos, tr. E. R. A. Sewter (London: Penguin, 1979), V.40-50, 145-151.

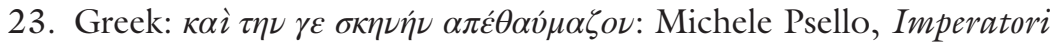
di Bisanzio (Cronografia), ed. and tr. Salvatore Impellizari, Ugo Criscuolo and Siliva Ronchey, 2 vols (Milan: Fondazione Lorenzo Valla/Mondadori, 1984), I, 234.

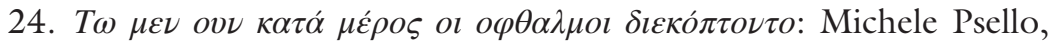
Imperatori, 240.

25. Garland-Thomson, Staring, 27, points out that "fascination" is etymologically linked to the Latin for being "bewitched" or caught in the evil eye.

26. Anna Comnène, Alexiade, I.6, ed. and tr. Bernard Leib, 3 vols (Paris: Les Belles Lettres, 1967) [hereafter Alexiad]. English translations throughout from Anna Komnena, Alexiad, tr. E. R. A. Sewter (London: Penguin, 1969) [hereafter Sewter], here at 45 .

27. Alexiad, I.9 (Sewter, 52). Greek: Alexiade, ed. Leib, I, 36.

28. Alexiad, IX.9 (Sewter, 289).

29. Below, Chap. 7.

30. Alexiad, I.7: Alexius hands Bryennius over to Borilos, envoy of the emperor, who "did what he did": Sewter, 46; VII.2 Alexius "handed [him] over to Borilos with his sight undamaged": Sewter, 219. 
31. Threat: Alexiad XII.8: Isaac Contostephanos sent to intercept the Norman leader Bohemond at Dyrrhachium with the threat that his eyes would be gouged if he failed to arrive there before Bohemond crossed the Adriatic. Rumor: the case of Nicephorus Diogenes, already discussed. Simulation: the case of Roussel, discussed here, and of Alakaseos, who pretended to have been mistreated by the emperor to flush out another traitor: Alexiad, X.4.

32. Alexiad I.3 (Sewter, 36). Greek: Alexiade, I, 15.

33. Alexiad I.4 (Sewter, 37). Greek: Alexiade, I, 16.

34. William Ian Miller, Humiliation and Other Essays on Honor, Social Discomfort and Violence (Ithaca/London: Cornell University Press, 1998), 66, comments that noise functions as part of the sign system of pain, where groans and screams replace words.

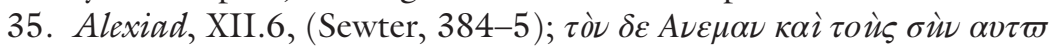

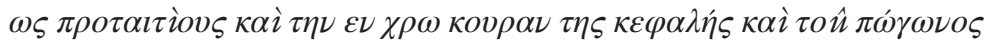

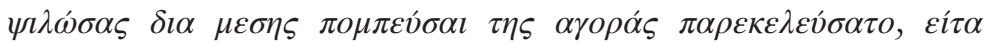

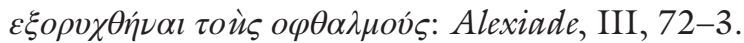

36. The power of face-to-face looking between victim and spectator, Garland-Thomson comments, led to the hooding of those going to execution from the seventeenth century onwards: Staring, 54.

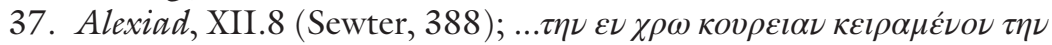
$\kappa \varepsilon \varphi \alpha \lambda \dot{\eta} \nu \tau \varepsilon \kappa \alpha i \tau o \nu ~ \pi \omega ́ \gamma \omega \nu \alpha$ : Alexiade, III, 77.

38. Above, Chap. 3.

39. Orderic, XII.39 (VI, 352-6).

40. Alexiad I.11 and V.5 (Robert); XI.10 (Bohemond); II.4 (threat to Alexius); XV.6 (Malik-Shah, Sewter, 490-1).

41. Self and Society in Medieval France: the Memoirs of Abbot Guibert of Nogent, II.7, ed. and tr. John Benton (New York: Harper, 1970), 170 (African). For Alais see above, Chap. 5.

42. Self and Society, II.3, 150.

43. Self and Society, III.5, 159 (Gérard), 8 and 9, 176 and 181 (Gaudry).

44. Self and Society, II.5, 137-8.

45. http://savingfaces.co.uk/news-media/art-project/35-newsmedia/art/15-art-exhibition [Accessed 12 July 2015]. 
46. Bible: Andre Grabar and Carl Nordenfalk, Early Medieval Painting (Paris: Skira, 1957), 153. Most of the Lombard portraits are available to view on the Getty Images website: www.getty.co.uk [accessed 11 April 2015]. Paul Edward Dutton and Herbert Kessler, The Poetry and Paintings of the First Bible of Charles the Bald (Ann Arbor: University of Michigan Press, 1997), 43.

47. Moreover, the names allow for identification of some of the women: Fiona Griffiths, The Garden of Delights: Reform and Renaissance for Women in the Twelfth Century (Philadelphia: University of Pennsylvania Press, 2006), 28.

48. Willibald Sauerländer, "The fate of the face in medieval art," in Set in Stone: the Face in Medieval Sculpture, ed. C. T. Little (New York: Metropolitan Museum, 2006), 3-17, at 3-4.

49. Retrospective portraits of Charlemagne as donor are visible, for example, twelfth-century decorative schemes: Thomas E. A. Dale, Relics, Prayer and Politics in Medieval Venetia: Romanesque Painting in the Crypt of Aquileia Cathedral (Princeton: Princeton University Press, 1997), 40-41.

50. Grabar and Nordenfalk, Early Medieval Painting, 58 (portrait), 126 (Merovingians), 17 (Carolingians) and 56 and 79 (Christ healing).

51. Carolyn L. Connor, Women of Byzantium (New Haven: Yale University Press, 2004), 236.

52. Canterbury Cathedral, Trinity Chapel, North Aisle, North Window, panels 16-19.

53. Gesta Guillelmi of William of Poitiers, I.3, ed. and trans. R. H. C. Davis and M. Chibnall (Oxford: Clarendon Press, 1998), reports that the attempted blinding of Alfred, son of Aethelred, in 1036 with a knife went wrong, damaging his brain and thus killing him.

54. Garland-Thomson, Staring, 25-6.

55. The Journey through Wales, I.11, tr. Thorpe, 142-3.

56. ibid., I.1, tr. Thorpe, 77-8.

57. Eye for an Eye, 136.

58. Sarah Alison Miller, Medieval Monstrosity and the Female Body (London: Routledge, 2010), explores the longevity of this theme from the Church Fathers to the De Secretis Mulierum of the latethirteenth/early-fourteenth century. 
59. Pactus Legis Salicae, XXXI.2, ed. K. Eckhardt, MGH LL nat. Germ., IV.1 (Hannover: Hahn, 1962), 121; Lex Salica, XXXVIII.2, ed. K. Eckhardt, MGH LL nat. Germ., IV.2 (Hannover: Hahn, 1959), 215; Leges Langobardorum, Rothari 26 and 171, ed. F. Bluhme in MGH LL, IV, ed. G. H. Pertz (Hannover: Hahn, 1868), 17 and 86.

60. See above, Chap. 5 , for more on this "jurisdictional space."

61. For a modern presentation of way-blocking a young woman, compare the dark [and threatening] spatial dynamics in the pop video for Michael Jackson's “The Way You Make Me Feel,” (dir. J. Pytka, 1987), contrasting markedly with the breezy tone and lyrics of the song itself.

62. See the brief controversy over the now-withdrawn rape awareness campaign by Sussex Police in the UK to encourage groups of women on a night out not to "leave their mate behind": http:// www.bbc.co.uk/news/uk-england-sussex-32255606, accessed 11 April 2015.

63. Colin Morris, The Discovery of the Individual, 1050-1200 (New York and London: Harper and Row, 1972).

64. Mark Pendergast, Mirror, Mirror: A History of the Human Love Affair with Reflection (New York: Basic Books, 2003), 117-118.

65. The literature on these texts is extensive: Herbert Grabes, The Mutable Glass: Mirror-Imagery in Titles and Texts of the Middle Ages and English Renaissance (Cambridge: Cambridge University Press, 1982); Le prince au miroir de la littérature politique de l'Antiquité aux Lumières, ed. F. Lachaud and L. Scordia (Rouen: Publications des universités de Rouen et du Havre, 2007), especially Rachel Stone, "Kings are different: Carolingian mirrors for princes and lay morality," 69-86; Linda Darling, "Mirrors for princes in Europe and the Middle East: a case of historiographical incommensurability," in East Meets West in the Middle Ages and Early Modern Times: Transcultural Experiences in the Premodern World, ed. A. Classen (Berlin: DeGruyter, 2013), 223-242.

66. Pendergast, Mirror Mirror, 120-121, discusses some early examples of ecclesiastical texts using this image.

67. I am grateful to Kristi Upson-Saia for advice on this point. See her "Resurrecting deformity: Augustine on wounded and scarred bodies in the heavenly realm", in Disability in Judaism, Christianity, 
and Islam: Sacred Texts, Historical Traditions, and Social Analysis, ed. Darla Schumm and Michael Stoltzfus (New York: Palgrave Macmillan, 2011), 93-122; Candida Moss, "Heavenly healing: eschatological cleansing and the resurrection of the dead in the holy church," Journal of the American Academy of Religion, 79 (2011): 991-1017. Caroline Walker Bynum, The Resurrection of the Body (New York: Columbia University Press, 1995), 116, highlights that the mosaic of the Last Judgment at Torcello Cathedral near Venice depicts only the blessed rising whole, whilst the damned "are shown in a state of fragmentation that is a symbolic expression of their sins."

Open Access This chapter is distributed under the terms of the Creative Commons Attribution 4.0 International License (http://creativecommons.org/licenses/by/4.0/), which permits use, duplication, adaptation, distribution and reproduction in any medium or format, as long as you give appropriate credit to the original author(s) and the source, provide a link to the Creative Commons license and indicate if changes were made.

The images or other third party material in this book are included in the work's Creative Commons license, unless indicated otherwise in the credit line; if such material is not included in the work's Creative Commons license and the respective action is not permitted by statutory regulation, users will need to obtain permission from the license holder to duplicate, adapt or reproduce the material.

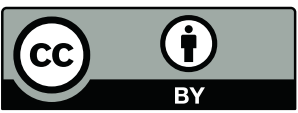

